\title{
Solving Child Statelessness: Disclosure, REPORTING, AND CORPORATE RESPONSIBILITY
}

\author{
Mark K. Brewer* \& Sue Turner**
}

\begin{abstract}
Statelessness affects around 10 million people globally, many of whom are children. Many public law initiatives to diminish and eradicate statelessness exist, yet the problem persists. This article explores the potential for the private law to contribute to a solution to this problem, leading to increased awareness of the plight of stateless children among the public, investors, governments, and multinational corporations. In doing so, the article examines the role of the private law in regulating the use of socalled "conflict minerals" in the United States and internationally. It recognizes the contribution made by conflict minerals legislation towards finding an effective solution to the conflict in the Democratic Republic of the Congo. The article proposes, amongst other initiatives, a legislative solution to the enduring problem of child statelessness, adapting provisions of the Dodd-Frank Wall Street and Consumer Protection Act which requires corporate reporting and disclosure in relation to international supply chains of public limited companies in respect of conflict minerals, and applying them instead to the causes of child statelessness.
\end{abstract}

\section{KEYWORDS}

Child Statelessness, Corporate Social Responsibility, Dodd-Frank Act, Conflict Minerals, Modern Slavery

\section{CONTENTS}

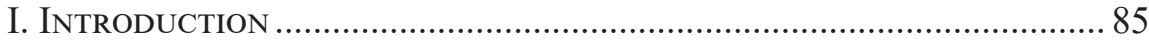

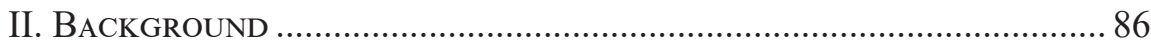

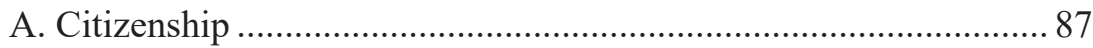

B. International Legal Framework for Protecting Human Rights and

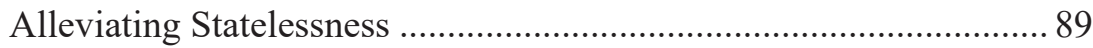

C. Overview of Conflict Minerals .................................................. 91

1. The United States Legal Response ........................................... 92

2. The European Legal Response .............................................. 93

* Assistant Dean, Sheffield Business School, Sheffield Hallam University; B.A., Samford University; Ph.D., University of St Andrew; J.D., Cornell University; M.LL.P., Humboldt Universität zu Berlin.

** Senior Lecturer, Northumbria Law School, Northumbria University; B.A., Lancaster University. 
3. The Chinese Legal Response ................................................... 94

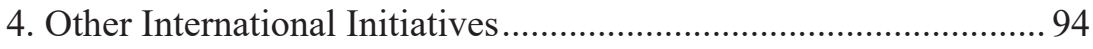

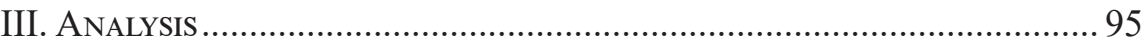

A. A Private Law Solution Based on Initiatives and Corporate

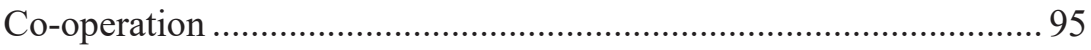

B. A Private Law Solution Based on Section 1502 of the Dodd-Frank

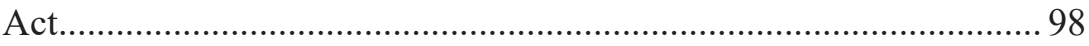

1. Legislative Proposal..................................................................... 98

2. Legal Precedent for Private Law Solutions for Public Law

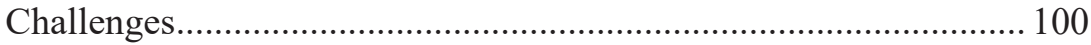

3. Reporting under Section 1502 of the Dodd-Frank Act............... 101

4. Declaration under Section 1502 of the Dodd-Frank Act ............. 103

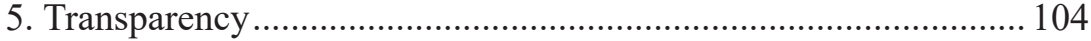

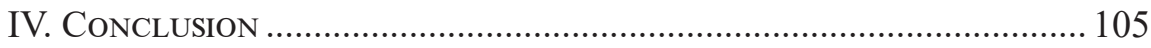




\section{INTRODUCTION}

Stateless children face a number of legal and practical challenges, including no legal identity, denial of healthcare, a lack of access to social welfare and child protection systems, limited assistance during emergencies, inadequate protection from violence and abuse, exploitation through child labor, and the lack of minor status vis-à-vis the law. Stateless children also lack the legal prerequisites to qualify for employment, to obtain travel documents, or even verify their age. Despite decades of international efforts accompanied by a proliferation of international law, statelessness remains a persistent problem, ${ }^{1}$ with the United Nations High Commissioner for Refugees ("UNHCR") estimating that there are at least 10 million stateless people internationally. ${ }^{2}$

Just as the problem of stateless children is global, so too is the reach of many multinational corporations. There are some areas of the globe which are home to a specific and identifiable group of stateless individuals who fall within the reach of multinational corporations, whether directly or as part of an essential supply chain. ${ }^{3}$ In the Dominican Republic, for example, a large number of stateless persons continue to work in the sugar cane industry despite the introduction of some local legal provisions intended to diminish this problem. ${ }^{4}$ Likewise, a number of reports have highlighted the reliance on migrant labor which exacerbates issues of statelessness in the global palm oil industry. ${ }^{5}$ The engagement of multinational corporations operating in affected areas could be the key to raising global awareness of statelessness and to driving and encouraging the success of local initiatives, education, and legal measures designed to alleviate statelessness.

The past few years have witnessed a number of initiatives, particularly Section 1502 of the Dodd-Frank Wall Street Reform and Consumer Protection Act ${ }^{6}$ (the "Dodd-Frank Act"), that combine elements of public and private law to address the long-standing conflict in the Democratic Republic of the Congo (the "DRC"), which often appeared beyond the reach of many international law initiatives. In

\footnotetext{
Jacqueline Bhabha, Arendt's Children: Do Today's Migrant Children Have a Right to Have Rights?, 31 Hum. RTs. Q. 410, 411 (2009).

2 UNHCR, Ending Statelessness within 10 Years, A Special Report, available at http://www. unhcr.org/pages/49c3646c155.html (last visited Aug. 24, 2018).

3 See Mark K. Brewer, Beyond International Law: The Role of Multinational Corporations in Reducing the Number of Stateless Children, 19 TiLBURG L. Rev. 64, 68 (2014).

4 Id. at 68.

$5 \quad$ See generally Dileep Kumar M., Noor Azizi Ismail \& Normala S. Govindarajo, Way to Measure the Concept Precarious Working Conditions in Oil Palm Plantations, 10 Asian Soc. Scr. 1 (2014) (reviewing empirical data and concluding that the "living condition [of migrant workers in the industry] is unsafe, insecure and highly isolated" id. at 7; Humans Taking Back Seat to Environment in Palm Oil Impact Talks, Activists Say, MalaY MaIL (Nov. 10, 2015), https://www.malaymail.com/s/1002673/humans-taking-back-seat-toenvironment-in-palm-oil-impact-talks-activists-s (noting that "stateless children. . . born to undocumented migrants . . could not gain access to government services, which include health and education); and Pulitzer Center, Lost in the Forest: Stateless Children in Borneo's Palm Oil Industry, https://pulitzercenter.org/projects/malaysia-lost-forest-stateless-childrenfilipino-migrant-workers-palm-oil-industry-social-environmental-cost (last visited Feb. 18, 2019).

$6 \quad$ P.L. 111-203, 124 Stat. 1376 (2010), 15 U.S.C. Section 78m(p).
} 
particular, these reforms require public disclosure of trade in so-called conflict minerals (i.e., tin, tungsten, tantalum, and gold ${ }^{7}$ ) which have been used to finance conflict in the DRC. In this manner, governments and investors have engaged with private law measures to contribute to a solution where public international law alone has failed to be effective. With on-going criticism of the Dodd-Frank Act and calls to dismantle large portions of it, ${ }^{8}$ it is all the more important to emphasize the applicability of the current provisions as well as indicate their relevance to address other problems that have eluded traditional regulation. In the same way in which the conflict minerals laws and initiatives have targeted companies operating directly or indirectly in affected areas, so might laws and initiatives seek to engage multinational corporations in an effort to eradicate the risks of statelessness to the migrant workers and their families involved in the supply chains of such multinational corporations. Recognizing the difficulty in eradicating statelessness and the efficacy of Dodd-Frank's conflict mineral provisions, this article calls for specific legal reform to address the causes of child statelessness through a similar approach to that for conflict minerals.

Part II of this article initially provides an overview of citizenship and statelessness. Further, it explores the plight of stateless children, contending that public law initiatives alone to date have been unsuccessful in their attempt to address this problem. Thereafter, the article sets out the background to the sourcing and usage of conflict minerals from the DRC and considers legal responses to this situation by (1) Congress in the form of Section 1502 of the Dodd-Frank Act; (2) the United Kingdom and the European Union; (3) China; and (4) international initiatives. Part III of this article analyses a number of possibilities for engaging multinational corporations in a private law response to the plight of stateless children around the globe.

This article contributes to research into the persistent problem of statelessness by identifying and exploring ways in which the private law may complement public law initiatives in an effort to combat child statelessness. In particular, this article proposes original legislation, based on existing U.S. provisions which address human rights violations related to conflict minerals. Given the international nature of child statelessness and the multinational response to existing conflict minerals legislation, the proposed new legislation, while founded in U.S. law, has the potential for global application, impacting upon multinational corporations around the world. As will be demonstrated in respect of U.S. conflict minerals legislation, adoption of legislation within the United States may contribute to further international private law initiatives, including in the United Kingdom, the European Union, and China.

\section{BACKGROUND}

Before examining particular mechanisms through which companies could potentially help alleviate child statelessness, this section provides an overview of citizenship,

\footnotetext{
7 Karen E. Woody, Conflict Minerals Legislation: The SEC's New Role as Diplomatic and Humanitarian Watchdog, 81 FordHAm L. Rev. 1315, 1319 (2013).

8 Nicola Dalla Via \& Paolo Perego, Determinants of Conflict Minerals Disclosure Under the Dodd-Frank Act, Bus. STRAT. Env. 1, 13 (2018).
} 
the public international law regime relevant to statelessness, and conflict minerals. First, this section examines the concept of citizenship, its origins, and the manner in which it is acquired. Second, the section summarizes the principal international agreements establishing the minimum legal standards regarding statelessness, particularly with respect to children. Third, this section outlines the issue of conflict minerals and examines the response of the United States, the United Kingdom and the European Union, China, and other international bodies.

\section{A. Citizenship}

A "stateless person" is one "who is not considered a national by any State under the operation of its law." Citizenship defines the relationship between the state and an individual. ${ }^{10}$ Concepts of citizenship have presupposed an autonomous political entity since ancient Greece. ${ }^{11}$ According to Aristotle, "[h]e who has the power to take part in the deliberative or judicial administration of any state is said by us to be a citizen of that state."12 Further, citizens have particular rights and obligations vis-à-vis the state. ${ }^{13}$ In Western thought, the state has served as the sovereign that guarantees the rights and enforces the obligations of citizens. ${ }^{14}$ Classical theory holds that "[s]overeignty is universal, and accordingly, the whole world is divided into these territorial units." 15 Nevertheless, various regimes throughout history have attached different rights and obligations to citizenship. ${ }^{16}$ As the first civilization to thoroughly explore citizenship, the ancient Greeks recognized specific responsibilities and rights compared to non-citizens. ${ }^{17}$ Aristotle further noted that "[s]ince there are many forms of government there must be many varieties of citizens ... so that under some government the mechanics and laborers

9 U.N. General Assembly, Convention Relating to the Status of Stateless Persons, 28 September 1954, United Nations, Treaty Series, vol. 360, p. 117, Art 1(1).

10 Ediberto Roman, Members and Outsiders: An Examination of the Models of United States Citizenship as Well as Questions Concerning European Union Citizenship, 9 U. MiAmI InT'L \& Comp. L. Rev. 81, 83 (2000/2001).

11 Kim Rubenstein \& Daniel Adler, International Citizenship: The Future of Nationality in a Globalized World, 7 Ind. J. Global Legal Stud. 519, 520 (2000).

12 See Roman, supra note 10, at 83, quoting The Basic Work of Aristotle, Aristotle's Politics, Book II (Richard McKeon ed. 1941), 1178.

13 See generally Thomas Janoski, Citizenship and Civil Society: A Framework of Rights and Obligations in Liberal, Traditional, and Social Democratic Regimes (Cambridge University Press, 1998), 1-8.

14 Steven J. Heyman, The First Duty of Government Protection: Liability and the Fourteenth Amendment 41 Duke L. J. (1991) 507, 513-520 (reviewing the common law tradition, the theory of natural rights and the social contract, and 18th Century constitutional theory).

15 Kim Rubenstein \& Daniel Adler, International Citizenship: The Future of Nationality in a Globalized World, 7 InD. J. Global Legal Stud. 519, 520 (2000).

16 See generally T.H. Marshall, Citizenship and Social Class, in CitizenshiP and Social Class (T.H. Marshall \& Tom Bottomore eds. 1992) 8-17 (summarizing the historical development of citizenship in the England).

17 Derek Heater, Citizenship: The Civic Ideal in World History, Politics and Education ( $3^{d}$ ed. 2004) 3-6. 
will be citizens." 18 Likewise, the ancient Roman Empire classified citizens in different categories, including those who had the right to vote and those who had an obligation to pay taxes. ${ }^{19}$

For many centuries, the term "citizen" was not used in Europe outside the Byzantine Empire. ${ }^{20}$ Instead, much of Europe used the term "subject," which reflected feudal law. ${ }^{21}$ From feudal law, various regimes began to recognize citizenship based on either jus soli or jus sanguinis. ${ }^{22}$ Jus soli requires that an individual be born in a territory over which the state maintains sovereignty, while jus sanguinis requires a blood tie to the state to acquire citizenship. ${ }^{23}$ According to "feudal traditions that linked people to the lord who held the land on which they were born[,]" jus soli was the primary determinant of citizenship in Europe in the eighteenth century. ${ }^{24}$ The French Revolution ushered in the reintroduction of the Roman concept of jus sanguinis with the French Civil Code of 1804, which precipitated its spread across continental Europe and, with some notable exceptions, to the colonies of the continental European powers. ${ }^{25}$ In contrast, the United Kingdom retained the concept of jus soli, spreading this form of citizenship throughout its colonies. ${ }^{26}$ In addition to the United Kingdom and Ireland, the United States and much of Latin America have exhibited jus soli in their concept of citizenship. ${ }^{27}$ In the common law world, the seminal 1608 case Calvin v. Smith ${ }^{28}$ provided the basis for jus soli. ${ }^{29}$ Lord Coke, writing for the court, determined that Calvin, who was born in Scotland after the crown of England passed to King James VI of Scotland, was a natural born subject and could therefore assert claims for land in England. ${ }^{30}$ The case firmly grounded territorial birth right citizenship (jus soli) in the common law. ${ }^{31}$ The United Kingdom modified the principle through the British Nationality Act of 1981, restricting citizenship to children born in the United Kingdom with at least one parent who is either a British citizen or "settled" in the United Kingdom ${ }^{32}$ Although the United States has traditionally followed jus

18 See Roman, supra note 10, at 83, quoting The Basic Work of Aristotle's Politics, Book II 1178 (Richard McKeon ed. 1941).

19 Id. at 90.

20 Polly Price, Natural Law and Birthright Citizenship in Calvin's Case, 9 Yale J.L. \& Human 73, 87 (1997).

21 Id. at 87-88. See also Justin Lewis, Constructing Public Opinion: How Political Elites Do What They Like and Why We Seem to Go along with It 22 (2001).

22 See generally John D. Snethen, The Evolution of Sovereignty and Citizenship in Western Europe: Implications for Migration and Globalization, 8 IND. J. GLOBAL LeGAL STUD. 223 (2000).

23 See Thomas Alexander Alenikoff et al., Citizenship Today: Global Perspective and Practice 17 (2001).

24 Grazielle Bertocchi \& Chiara Strozzi, The Evolution of Citizenship: Economic and Institutional Determinants, 53 J. L. \& ECON. 95,99 (2010).

25 Id. at $99-100$.

$26 \quad I d$.

$27 \quad I d$.

28 Calvin v. Smith (1608) 77 Eng. Rep. 377.

29 Id. 409.

$30 \quad$ Id. 408.

31 Price, supra note 20.

32 British Nationality Act 1981, ch. 61, §§ 1, 3 (Eng.). 
soli since its founding, ${ }^{33}$ and codified the principle in 1868 through the Fourteenth Amendment to the Constitution, it incorporates elements of jus sanguinis for children of U.S. citizens born overseas. ${ }^{34}$ Currently, jus sanguinis forms the most common means of determining citizenship among the countries of the world, ${ }^{35}$ and a large number of countries have mixed regimes that combine elements of both jus sanguinis and jus soli. ${ }^{36}$

\section{B. International Legal Framework for Protecting Human Rights AND ALLEVIATING STATELESSNESS}

A range of international treaties and agreements establish the minimum legal standards to which stateless children should be entitled. With the adoption of the United Nations Charter in 1945, the international community established a regime for the protection of basic human rights for all individuals against abuses by foreign sovereigns and by national governments themselves. ${ }^{37}$ In the decades following, the Universal Declaration of Human Rights; ${ }^{38}$ the International Covenant on Civil and Political Rights ${ }^{39}$ the International Covenant on Economic, Social, and Cultural Rights; ${ }^{40}$ the Convention on the Elimination of All Forms of Discrimination Against Women; ${ }^{41}$ the Convention on the Elimination on All Forms of Racial Discrimination; ${ }^{42}$ the Convention Against Torture and Other Cruel, Inhumane or Degrading Treatment or Punishment; ${ }^{43}$ and the Convention on the Prevention and Punishment of the Crime of Genocide ${ }^{44}$ have further strengthened rights of individuals against traditional notions of the unfettered power of sovereigns.

Further, a number of United Nations ("U.N.") treaties contain specific provisions offering protection against statelessness. The 1948 Universal

33 See generally Nora V. Demleitner, The Fallacy of Social 'Citizenship' or the Threat of Exclusion, 12 Geo. Immigr. L.J. 35, 37 (1997).

34 Ann Laquer Estin, Sharing Governance: Family Law in Congress and the States, 18 Cornell J. L. \& PuB. Pol'y 267, 325 (2009).

35 Bertocchi \& Strozzi, supra note 24, at 99-100. The authors note that 69 percent of African countries and 83 percent of Asian countries base their citizenship on jus sanguinis.

36 For a comparative analysis of the prevalence of jus soli and jus sanguinis, see generally Patrick Weil, Access to Citizenship: A Comparison of Twenty-Five Nationality Laws, in Citizenship Today: Global Perspectives and Practice (T. Alexander Alenikoff \& Douglas Klusmeyer eds. 2001), 17-35.

$37 \quad$ Id.

38 Universal Declaration of Human Rights, G.A. Res. 217A(III), U.N. GOAR, 3d sess., Supp. No. 13, U.N. Doc. A/810 (1948).

39 International Covenant on Civil and Political Rights, G.A. Res. 2200A (XXI), U.N. GAOR, Supp. No. 16, at 52, U.N. Doc. A/6316 (1966).

40 International Covenant on Economic, Social, and Cultural Rights, G.A. res. 2200A (XXI), U.N. GAOR, Supp. No. 16, at 49, U.N. Doc. A/6316 (1966).

41 Convention on the Elimination of All Forms of Discrimination Against Women, Dec. 18, 1979, 19 I.L.M. 33.

42 International Convention on the Elimination of All Forms of Racial Discrimination, Jan. 7, 1966, 5 I.L.M.

43 Convention Against Torture and Other Cruel, Inhumane or Degrading Treatment or Punishment, Dec. 10, 1984, 23 I.L.M. 1027, modified 24 I.L.M. 535.

44 Convention on the Prevention and Punishment of the Crime of Genocide, Dec. 9, 1948, 78 U.N.T.S. 277. 
Declaration of Human Rights provides a general right to nationality and prohibits the arbitrary deprivation of nationality. ${ }^{45}$ The 1954 Convention Relating to the Status of Stateless Persons (the "1954 Convention") defines statelessness and sets forth regulations for the treatment of stateless persons. ${ }^{46}$ In particular, Article 7 of the 1954 Convention provides that states "shall accord to stateless persons the same treatment as is accorded to aliens generally." ${ }^{47}$ Moreover, Articles 17-19 of the 1954 Convention ensure that stateless persons are treated no less favorably than aliens, in general, with respect to a number of employment considerations, ${ }^{48}$ while further provisions address housing ${ }^{49}$ public education, ${ }^{50}$ public relief, ${ }^{51}$ and labor standards and social security. ${ }^{52}$ The 1961 Convention for the Reduction of Statelessness (the "1961 Convention") provides for the "acquisition of nationality for those who would otherwise be stateless and who have an appropriate link with the State through factors of birth or descent." ${ }^{53}$ There are currently 67 states party to the 1961 Convention ${ }^{54}$ and 88 states party to the 1954 Convention. ${ }^{55}$

Several U.N. treaties address the issue of child statelessness in particular. The 1966 International Covenant on Civil and Political Rights recognizes the right of "[e]very child. . . to acquire a nationality," ${ }^{66}$ but it lacks any specific mechanism for compelling states to take responsibility for guaranteeing a stateless child's right to a nationality. ${ }^{57}$ Additionally, the U.N. Convention on the Rights of the Child, adopted in 1989 and in force since 1990, guarantees a child's right to a nationality under Art. $7 .^{58}$ Additionally, Art. 8 provides that children have a right to preserve their identity, which includes their nationality. ${ }^{59}$ The obligations created by the U.N. Convention on the Rights of the Child apply to both the child's country of birth and

45 Universal Declaration of Human Rights, Dec. 10, 1948, U.N. General Assembly 217A, Art. 15.

46 Convention Relating to the Status of Stateless Persons, April 26, 1954, 189 U.N.T.S. 150.

47 Id.

$48 \quad$ Id.

Id. at Art. 21.

Id. at Art. 22.

Id. at Art. 23.

Id. at Art. 24.

53 U.N. High Commissioner for Refugees, Objectives and Key Provisions of the 1961 Convention on the Reduction of Statelessness (Oct. 1, 2001), available at http://www.unhcr. org/3bd7d3914.html (last visited Aug. 24, 2018).

54 United Nations Treaty Collection, Status of Treaties, https://treaties.un.org/pages/ ViewDetails.aspx? $\mathrm{src}=\mathrm{TREATY} \& \mathrm{mtdsg} \_$no $=\mathrm{V}-4 \&$ chapter $=5 \&$ lang $=$ en (last visited Aug 24, 2018).

55 United Nations Treaty Collection, Status of Treaties, https://treaties.un.org/pages/ ViewDetailsII.aspx? src $=$ TREATY\&mtdsg_no $=V-3 \&$ chapter $=5 \&$ Temp $=$ mtdsg2\&clang $=$ en (last visited Aug. 24, 2018).

56 ICCPR, Article 24(3).

57 Human Rights Committee, General Comment 17, Article 24 (Thirty-fifth session, 1989), Compilation of General Comments and General Recommendations Adopted by Human Rights Treaty Bodies, U.N. Doc. HRI/GEN/1/Rev.1 at 23 (1994).

58 Convention on the Rights of the Child, United Nations General Assembly, 20 Nov. 1989, $\mathrm{A} / \mathrm{RES} / 44 / 25$ Article 7.

59 Convention on the Rights of the Child, United Nations General Assembly, 20 Nov. 1989, A/RES/44/25 Article 8 . 
to "all countries with which a child has a link, e.g. by parentage." ${ }^{60}$ Art. 1(3) of the Convention on the Rights of the Child provides that states must grant citizenship to children who otherwise would be stateless, addressing potential problems where national laws may not allow for a mother to transmit citizenship. ${ }^{61}$ Finally, the International Convention on the Protection of the Rights of All Migrant Workers and Members of Their Families, signed in 1990 and in force since 2003, provides that "[e]ach child of a migrant worker shall have the right to. . . a nationality." 62

In addition to international treaties, a number of regional agreements protect the status of stateless children. For example, the Council of Europe adopted the European Convention on Nationality that recognizes a universal right to nationality and provides that "statelessness should be avoided." ${ }^{63}$ Article 6 of the European Convention on Nationality includes specific protections that require each party to the agreement to "provide in ... [its] internal law for its nationality to be acquired by children born on its territory who do not acquire at birth another nationality."

Despite the array of public law initiatives that seek to alleviate the problem of statelessness, as stated above, the U.N. estimates that there are still around 10 million stateless people around the globe. ${ }^{65}$ Many of these are children. ${ }^{66}$ Not only may stateless children be deprived of basic medical care, state-supported educational programs, and other social programs, but they also lack the legal prerequisites to qualify for employment, to obtain travel documents, or even verify their age, which often exposes them to violence, exploitation, and abuse. ${ }^{67}$

Given the persistence of the problem of statelessness, this article proposes solutions beyond the realm of public international law by calling for the introduction of corporate disclosure requirements relating to statelessness in the supply chains of publicly listed companies similar to the reporting requirements relating to conflict minerals. Such a private law initiative would help supplement the protections offered by public international law.

\section{OVERVIEW of Conflict Minerals}

Concern over the ongoing conflict in the DRC, which has claimed over 5 million lives over the past few decades, ${ }^{68}$ galvanized efforts to regulate conflict

60 United Nations High Commissioner for Refugees, Expert Meeting: Interpreting the 1961 Statelessness Convention Preventing Statelessness among Children: Summary Conclusions (May 23-24, 2011), 2-3.

61 Convention on the Rights of the Child, G.A. Res. 44/25, Art. 1(3) (Nov. 20, 1989).

62 International Convention on the Protection of the Rights of All Migrant Workers and Members of Their Families, Art. 29.

63 Council of Europe, European Convention on Nationality, (Nov. 6, 1997, E.T.S. 166), Art. 4.

64 Id. Art. 6.

65 UNHCR, supra note 2.

66 UNHR, Statelessness Around the World, available at http://www.unhcr.org/uk/statelessnessaround-the-world.html (last visited Aug. 24, 2018).

67 See generally Jay Milbrandt, Stateless, 20 Cardozo J. InT'L \& Comp. L. 75, 92-93 (2011-2012).

68 U.N. Economic Commission for Africa, Special report on "The ICGLR Regional Initiative against the Illegal Exploitation of Natural Resources (RINR) and other Certification Mechanisms in the Great Lakes Region: Lessons Learned and Best 
minerals. ${ }^{69}$ Conflict minerals are ores that, when sold or traded, play a key role in helping to fuel this conflict and extensive human rights abuses in the DRC. ${ }^{70}$ Minerals in conflict areas within the DRC are often mined by artisanal and small-scale miners operating under severe working conditions. ${ }^{71}$ The mines are strategically important for financing armed groups involved in the conflict, who tax mineral extraction and trade, while miners and their families are exposed to violence and human rights violations. ${ }^{72}$ Conflict minerals are used extensively in jewelry as well as a variety of consumer products, particularly electronic items such as mobile phones and computers. ${ }^{73}$ The awareness of end-users of such products, the efforts of governments, and the involvement of corporations themselves have brought the issue of conflict minerals to the fore, resulting in legislation, or steps being taken towards legislation, to prevent the use of conflict minerals by corporations across the globe, including in the United States, the United Kingdom, the European Union, and China. ${ }^{74}$

\section{The United States Legal Response}

Recognizing that the humanitarian crisis in the eastern part of the DRC was financed partially through the trade of certain minerals originating from the $\mathrm{DRC},{ }^{75}$ Congress promulgated Section 1502 of the Dodd-Frank Act that President Obama signed into U.S. law on July 21, 2010. ${ }^{76}$ Section 1504 of the Dodd-Frank Act

Practices," 7 (2013), available at https://repository.uneca.org/handle/10855/22274 (last visited Feb. 21, 2019).

69 e.g. (i) the explanatory note to H.R. 4173 - 838; and (i) European Commission Press Release, 16 June 2016, EU political deal to curb trade in conflict minerals available at http://europa.eu/rapid/press-release_IP-16-2231_en.htm (last visited Aug. 24, 2018).

70 U.N. Economic Commission for Africa Special report on the The ICGLR Regional Initiative against the Illegal Exploitation of Natural Resources (RINR) and other Certification Mechanisms in the Great Lakes Region: Lessons Learned and Best Practices, 5.

71 EC Directorate-General for Trade Assessment for due diligence cost, benefit and related effects on selected operators in relation to the responsible sourcing of selected minerals, Final Report, Sept. 25, 2013, 8 .

72 Id.

73 Gudrun Franken et al., Certified Trading Chains in Mineral Production: A Way to Improve Responsibility in Mining, in Non-Renewable Resource Issues: 213 Geoscientific and Societal Challenges (R. Sinding-Larsen \& F.-W. Wellmer eds. 2012) 213, 219.

74 For the United States, see H.R. 4173 - 833; for the European Union, see European Commission Press Release, 16 June 2016, EU political deal to curb trade in conflict minerals available at http://europa.eu/rapid/press-release_IP-16-2231_en.htm (last visited Aug. 24, 2018); for China, see Clause 2.4.6 CCMC Guidelines for Social Responsibility for Outbound Mining Investments available at https://www.globalwitness.org/sites/default/files/library/ CCCMC\%20Guidelines\%20for\%20Social\%20Resposibility\%20in\%20Outbound\%20 Mining\%20Investments\%20Oct\%202014\%20CH-EN_1.pdf (last visited Aug. 24, 2018).

75 Section 1502(a), Dodd-Frank Act: "It is the sense of Congress that the exploitation and trade of conflict minerals originating in the Democratic Republic of the Congo is helping to finance conflict characterized by extreme levels of violence in the eastern Democratic Republic of the Congo, particularly sexual- and gender-based violence, and contributing to an emergency humanitarian situation therein, warranting the provisions of section 13(p) of the Securities Exchange Act of 1934."

76 The White House Office of the Press Secretary, Remarks by the President at Signing of Dodd-Frank Wall Street Reform and Consumer Protection Act (Jul. 21, 2010), available 
mandates the U.S. Securities and Exchange Commission ("SEC") to require companies that file an annual report7 ${ }^{77}$ with the SEC (hereinafter, "reporting companies") to disclose details of their purchase of columbite-tantalite (coltan from which tantalum is extracted), cassiterite (tin), gold, wolframite (tungsten), or their derivatives ("conflict minerals") ${ }^{78}$ from the DRC and adjoining countries. ${ }^{79}$ In addition, reporting companies must ensure their suppliers comply with guidelines for tracing the source of minerals they use in manufacturing the reporting companies' products. ${ }^{80}$ Pursuant to Section 1502 of the Dodd-Frank Act, the SEC's final rules ${ }^{81}$ have required reporting companies since January 1, 2013 to determine if conflict minerals are required for the functionality or production of the goods that the reporting companies manufacture. ${ }^{82}$ The SEC final rules also require reporting companies to disclose any such conflict minerals on SEC Form SD by May 31 for the prior calendar year. ${ }^{83}$

\section{The European Legal Response}

Following a public consultation beginning in March 2013 to consider the sourcing of minerals from conflict zones or other high risk areas ${ }^{84}$ the European Commission proposed a voluntary self-certification scheme in March 2014 for importers of tin, tantalum, tungsten, and gold into the European Union. ${ }^{85}$ In June 2016, the European Parliament, the European Commission, and relevant ministers reached an understanding that due diligence for all but the smallest importers would in fact be mandatory. ${ }^{86}$ The law also encourages large U.K. manufacturers or sellers of goods which contain tin, tungsten, tantalum, or gold to report on their sourcing practices ${ }^{87}$ In the United Kingdom, the British Foreign and Commonwealth Office has issued

at https://obamawhitehouse.archives.gov/the-press-office/remarks-president-signing-doddfrank-wall-street-reform-and-consumer-protection-act (last visited Aug. 24, 2018).

77 See 15 U.S.C. $78 \mathrm{~m}(\mathrm{p})(2)(\mathrm{A})$.

78 Section 1502(e)(4), Dodd-Frank Act.

79 Section 1502(e)(1), Dodd-Frank Act. Adjoining countries include Angola, Burundi, Central African Republic, the Republic of the Congo, Rwanda, South Sudan, Tanzania, Uganda, and Zambia.

$80 \quad$ See 15 U.S.C. $78 \mathrm{~m}(\mathrm{p})(1)(\mathrm{A})(\mathrm{i})$.

81 Securities and Exchange Commission, Release No. 34-67716; File No. S7-40-10, 17 C.F.R. Parts 240 and 249b, available at http:/www.sec.gov/rules/final/2012/34-67716.pdf (last visited Aug. 27, 2018).

8217 C.F.R. Section $240.13 p-1$.

83 Id.

84 European Commission, EU Calls for input on "conflict minerals" (Mar. 27, 2013), http:// trade.ec.europa.eu/doclib/press/index.cfm?id=882 (last visited Aug. 24, 2018.

85 European Commission, EU proposes responsible trading strategy for minerals from conflict zones (Mar. 5, 2014), http://europa.eu/rapid/press-release_IP-14-218_en.htm (last visited Aug. 24, 2018).

86 European Parliament, Conflict minerals: MEPs Secure Mandatory Due Diligence for Importers (June 16, 2016), http://www.europarl.europa.eu/news/en/newsroom/20160615IPR32320/conflict-minerals-meps-secure-mandatory-due-diligence-forimporters (last visited Aug. 24, 2018).

87 Id. 
guidance $^{88}$ to encourage companies which trade in minerals originating in the DRC to be "socially, economically and environmentally responsible, including adhering to the relevant voluntary ... guidance and guidelines." 89

\section{The Chinese Legal Response}

On October 24, 2014, ${ }^{90}$ the China Chamber of Commerce of Metals, Minerals \& Chemicals Importers \& Exporters (“CCCMC") introduced its Chinese Due Diligence Guidelines for Responsible Mineral Supply Chains (the "Chinese Guidelines") in support of Clause 2.4.6 of the CCCMC Guidelines for Social Responsibility for Outbound Mining Investments. ${ }^{91}$ The Chinese Guidelines are based on the U.N. Guiding Principles on Business and Human Rights and the Organization for Economic Cooperation and Development (“OECD") Due Diligence Guidance on Responsible Supply Chains of Minerals from Conflict-Affected and HighRisk Areas and apply to "all Chinese companies which are extracting, trading, processing, transporting, and/or otherwise using mineral resources and their related products and are engaged at any point in the supply chain of mineral resources and their related products. $" 92$

The acknowledgement that adherence by Chinese companies will allow these companies to do business in a compliant fashion in jurisdictions which have their own conflict minerals laws and regulations "and/or achieve conformance with industry initiatives that improve market access" $" 93$ suggests that global conflict minerals legislation such as the Dodd-Frank Act has prompted the promulgation of the Chinese Guidelines. ${ }^{94}$

\section{Other International Initiatives}

In addition to the Dodd-Frank Act and initiatives in the European Union, the United Kingdom, and China, various international organizations have produced guidelines relating to conflict minerals. First, the OECD has formulated its Due Diligence Guidance for Responsible Supply Chains of Minerals from Conflict-Affected and High-Risk Areas (the "OECD Due Diligence Guidance") as mentioned above.95

F8 Foreign \& Commonwealth Office, Conflict Minerals: Encouraging British Companies Trading in Minerals from the Democratic Republic of Congo to Be Socially, Economically and Environmentally Responsible (Jun. 19, 2013), https://www.gov.uk/conflict-minerals (last visited Aug. 24, 2018).

89 Id.

90 China Chamber of Commerce of Metals, Minerals \& Chemicals Importers \& Exporters, Chinese Due Diligence Guidelines for Responsible Mineral Supply Chains, 3, available at https://mneguidelines.oecd.org/chinese-due-diligence-guidelines-for-responsible-mineralsupply-chains.htm (last visited Aug. 24, 2018).

$91 \quad I d$.

$92 \quad I d$. at 10.

93 Id. at 8.

94 Id.

95 OECD, OECD Due Diligence Guidance for Responsible Supply Chains of Minerals from Conflict-Affected and High-Risk Areas: Third Edition, 2016, available at http://dx.doi. org/10.1787/9789264252479-en_(last visited Aug. 24, 2018). 
Second, the World Gold Council Conflict-Free Gold Standard and the London Bullion Market Association (LBMA) Responsible Gold Guidance both have promulgated guidelines related to conflict minerals. ${ }^{96}$

\section{ANALYSIS}

Having examined the issue of child statelessness, the challenges inherent in the public international law to fully alleviate the problem, and the manner in which the global community has responded to conflict minerals, this section analyzes a number of possibilities for engaging multinational corporations, including the potential for particular legislation to address the problem of statelessness. First, the section examines the relevance of corporate governance and corporate social responsibility in encouraging ethical behavior in companies. Second, the section analyzes the Dodd-Frank Act's approach to conflict minerals as a template for addressing the issue of statelessness, proposing a draft text as a means to encourage action as well as critically examining the suitability, challenges, and criticisms of such an approach.

\section{A. a Private Law Solution Based on Initiatives and Corporate CO-OPERATION}

Although no one generally accepted definition exists, ${ }^{97}$ corporate governance seeks to enhance transparency, efficiency, and accountability in organizations while making such organizations more responsive to their various stakeholders. ${ }^{98}$ International corporate governance standards are a form of "soft law" formulated upon the recommendations of NGOs in consultation with national regulators.9 Several international organizations, notably the OECD, have formulated international corporate governance standards which seek to identify best practices and to formulate model codes of principles that typically promote effective corporate governance through fair and transparent markets; promote the equitable treatment of shareholders; encourage disclosure and transparency of material information; address the roles of institutional investors, stock exchanges, and other institutions; protect minority shareholders; and promote the responsibility, effectiveness, and accountability of management boards. ${ }^{100}$ International financial market integration,

$96 \quad$ See World Gold Council, Conflict-Free Gold Standard, Oct. 2012, available at http://www. gold.org/sites/default/files/documents/Conflict_Free_Gold_Standard_English.pdf(last visited Aug. 24, 2018) and LBMA Responsible Gold Guidance Version 6, $\overline{1} 4$ Aug. 2015, available at http://www.lbma.org.uk/assets/market/gd1/RGG\%20v6.0\%20201508014.pdf_last visited Aug. 24, 2018).

97 Steven M. Mintz, Corporate Governance in an International Context: Legal Systems, Financing Patterns and Cultural Variables, 13 CORP. Governance 582, 584 (2005).

98 Klaus J. Hopt, Comparative Corporate Governance: The State of the Art and International Regulation, 59 Ам. J. Coмp. L. 1, 6-7 (2011).

99 See generally Kevin Jackson, Global Corporate Governance: Soft Law and Reputational Accountability, 35 BrooK. J. INT'L L., 41, 44-47 (2010).

100 OECD, G20/OECD Principles of Corporate Governance, 2015, available at http://dx.doi. org/10.1787/9789264236882-en (last visited Jan. 23, 2017). 
competition among various national approaches to corporate governance, and harmonization of accounting standards have all contributed to convergence of international corporate governance best practices. ${ }^{101}$

While the dominant consensus in the Anglo-American concept of corporations has emphasized the maximization of shareholder value measured by share price, ${ }^{102}$ increasingly companies are determining that many considerations other than maximizing short-term profits actually contribute to their medium- and long-term viability. ${ }^{103}$ An appreciation of the various stakeholders in a company and their respective duties and obligations is fundamental to understanding the different constituents that may influence companies. ${ }^{104}$ Such concepts of corporate social responsibility have also played an increasingly important role in effecting corporate behavior. ${ }^{105}$ The growing interest in CSR has led to the launch of a number of stock market indices tracking companies that market participants identify with high standards of CSR, ${ }^{106}$ including the Dow Jones Sustainability Index ${ }^{107}$ and the FTSE4Good Index. ${ }^{108}$ Depending on the success of such indices, investors may collectively indicate their preference for more enhanced corporate governance and CSR standards. ${ }^{109}$

As no international body has the authority to enforce a global set of corporate governance standards, the only effective means of regulatory enforcement remains at the national level where both the particular emphasis of codes and levels of adherence vary considerably. ${ }^{110}$ Additionally, there is considerable variation in the administration and enforcement of codes in different countries, where codes may be mere recommendations or mandatory law and enforcement may be through stock exchanges or special commissions. ${ }^{111}$ Despite these differences, corporate

101 Toru Yoshikawa \& Abdul A. Rasheed, Convergence of Corporate Governance: Critical Review and Future Directions, 17 CoRp. GovernANCE: An INT'L Rev. 388, 390-392 (2009).

102 See generally Lynn Stout, The Shareholder Value Myth: How Putting Shareholders First Harms Investors, Corporations, and The Public, 2012 (Professor Stout notes: "According to the doctrine of shareholder value, public corporations "belong" to their shareholders, and they exist for one purpose only, to maximize shareholders' wealth." Id. at 2).

103 See generally Manuela Weber, The Business Case for Corporate Social Responsibility: A Company-Level Measurement Approach for CSR, 26 EuR. MGMt J. 247, 248-252 (2008).

104 Id. at 252-253.

105 Jose-Manuel Prado-Lorenzo, Isabel Gallego-Alvarez \& Isabel M. Garcia-Sanchez, Stakeholder Engagement and Corporate Social Responsibility Reporting: the Ownership Structure Effect, 16 Corp. Soc. Resp. Envtl. MGMt. 94, 94-95 (2009).

106 Michael Robinson, Anne Kleffner \& Stephanie Bertels, Signaling Sustainability Leadership: Empirical Evidence of the Value of DJSI Membership, 101 J. Bus. EтнICs 493, 493-496 (2011).

107 See DJSI Annual Review, available at http://www.robecosam.com/en/sustainabilityinsights/about-sustainability/corporate-sustainability-assessment/review.jsp (last visited Aug. 28, 2018).

108 See FTSE4Good Index Series, http://www.ftse.com/products/indices/FTSE4Good (last visited Aug. 28, 2018).

109 See generally M. Victoria López, Arminda Garcia \& Lazaro Rodriguez, Sustainable Development and Corporate Performance: A Study Based on the Dow Jones Sustainability Index, 75 J. of Bus. EтHics 285, 286-287 (2007).

110 Hopt, supra note 98, at 13.

111 Id. at $14-15$. 
governance standards may provide a means to positively influence corporate behavior where traditional law has not been effective. Moreover, as "corporate governance becomes increasingly driven by ethical norms and the need for accountability," 112 companies have become more willing to enhance stakeholder engagement and investor accountability. ${ }^{113}$ In addition, governments could be prompted to formulate guidelines indicating how corporations may take positive steps to alleviate statelessness, similar to the British Foreign and Commonwealth Office guidelines ${ }^{114}$ issued in respect to the conflict minerals trade.

The U.N. Guiding Principles on Business and Human Rights"15 (the "Guiding Principles") is an example of a set of international principles for states and businesses alike to meet the objective of "enhancing standards and practices with regard to business and human rights." that businesses have an impact on global human rights and are ideally placed to influence practices under either their direct or indirect control, and the direction within these Guiding Principles to businesses to respect human rights is clear and unequivocal. ${ }^{117}$ By their nature as general guiding principles, no specific actions are required in relation to conflict minerals or other human rights abuses, leaving compliance with the Guiding Principles in this arena to the judgement of those states and businesses which may commit to follow them. ${ }^{118}$

Beyond compliance with corporate governance standards or guidance issued at governmental levels, corporations have adopted codes of ethics for decades although many "were adopted in response to highly publicized scandals and/or major legal developments." 119 Corporate codes often recognize the importance of "treat[ing] stakeholders and competitors with fairness and respect." 120 Even though corporate codes may be dismissed as "empty exercises in "window dressing," 121 they "are most often perceived as tangible evidence that an organization has recognized a need for,

112 Amiram Gill, Corporate Governance as Social Responsibility: A Research Agenda, 26 BERKELEY J. INT'L LAW, 452, 463 (2008).

113 Id. at 454

114 Foreign \& Commonwealth Office, Conflict Minerals: Encouraging British Companies Trading in Minerals from the Democratic Republic of Congo to Be Socially, Economically and Environmentally Responsible, supra note 88.

115 United Nations, Guiding Principles for Business and Human Rights: Implementing the United Nations "Protect, Respect, and Remedy" Framework, HR/PUB/11/04, https://www. unglobalcompact.org/library/2 (last visited Aug. 28, 2018).

116 Id. at 1.

117 For a list of companies who have issued company policy statements on human rights, see Business \& Human Rights Resource Centre, Company Policy Statements on Human Rights, $\mathrm{http}$ //business-humanrights.org/en/company-policy-statements-on-human-rights (last visited Aug. 28, 2018).

118 Robert C. Blitt, Beyond Ruggie's Guiding Principles on Business and Human Rights: Charting an Embracive Approach to Corporate Human Rights Compliance, 48 Tex. INT'L L.J. 33, 43-44 (2012).

119 Joshua A. Newberg, Corporate Codes of Ethics, Mandatory Disclosure, and the Market for Ethical Conduct, 29 Vт. L. Rev. 253, 255 (2004-2005).

120 Id. at 261.

121 Id. at 264-265. The author notes: "Enron Corporation, wherein a detailed and famously earnest code of ethics coexisted with a great deal of now infamously unethical conduct, could be offered as 'exhibit A' for the 'window dressing' view of corporate codes." Id. at 265. 
and has made a commitment toward, ethical behavior." 122 Companies such as The Body Shop, ${ }^{123}$ People Tree, ${ }^{124}$ Ben \& Jerry's, ${ }^{125}$ and other companies with sociallyconscious codes of ethics have been influential in addressing particular areas of concern to their stakeholders. While empirical data on the efficacy of codes is inconclusive, ${ }^{126}$ there is evidence that credible information on ethical policies has a positive influence on consumer attitudes toward companies. ${ }^{127}$ It follows that enhanced disclosure obligations on the problem of statelessness, together with other human rights abuses such as those arising out of the conflict minerals crisis would provide shareholders and other stakeholders the very type of information that can promote corporate transparency and reputation. Accordingly, there may be scope for multinational corporations to compile a corporate code or framework setting out steps they may realistically take to address the issue of statelessness.

\section{B. A Private LaW Solution Based on SeCtion 1502 OF THE DODD-FRANK ACT}

\section{Legislative Proposal}

The precedent set by the SEC reporting obligations relating to conflict minerals provides a realistic and achievable way to engage multinational corporations in the effort to end statelessness. The wording of suggested legislation to achieve this aim is proposed below, adapted from the text of Section 1502 of the Dodd-Frank Act, replacing the original conflict minerals text with guidelines to address statelessness:

(A) Not later than 270 days after the date of the enactment of this provision, the Securities and Exchange Commission shall promulgate regulations requiring any person with an obligation to provide filings with the Commission to disclose annually, beginning with the person's first full fiscal year that begins after the date of promulgation of such regulations, whether employees of the person, employees within the supply chain of the person or children of such employees were stateless and submit to the Commission a report that includes, with respect to the period covered by the report: ${ }^{128}$

(i) a description of the measures taken by the person (a) to exercise due diligence on the citizenship of their employees, the employees within their supply chains and the children of such employees; and (b) to work

122 Cynthia Stohl, Michael Stohl \& Lucy Popova, A New Generation of Corporate Codes of Ethics, 90 J. Bus. Ethics, 607, 609 (2009).

123 The Body Shop, Our Commitment, https://www.thebodyshop.com/en-gb/about-us/ourcommitment (last visited Aug. 28, 2018).

124 People Tree, Our Story, http://www.peopletree.co.uk/about-us/mission (last visited Aug. 28, 2018).

125 Ben \& Jerry's, Values: How We Do Business, http://www.benjerry.com/values/how-we-dobusiness (last visited Aug. 28, 2018).

126 Newberg, supra note 119, at 266.

127 Lois A. Mohr \& Deborah J. Webb, The Effects of Corporate Social Responsibility and Price on Consumer Responses, 39 J. Consumer AfF., 121, 142-143 (2005).

128 Adapted from 15 U.S.C. Section $78 \mathrm{~m}(\mathrm{p})(1)(\mathrm{A})$. 
with local communities, agencies, and other governmental authorities in regions where stateless persons or children have been disclosed pursuant to paragraph (A) to raise awareness of the presence of stateless persons and children and to encourage the implementation of policies to reduce the number of stateless persons and children; ${ }^{129}$ and

(ii) a description of the policies adopted by the person to (a) assist employees and the employees within their supply chain to register such employees and the children of such employees as citizens; and (b) to monitor the success rates of such efforts. ${ }^{130}$

(B) For the purposes of this paragraph, a person may declare that it is "Supporting Stateless Children" if the measures and policies set out at paragraph (A) are implemented. ${ }^{131}$

(C) INFORMATION AVAILABLE TO THE PUBLIC.-Each person shall make available to the public on the Internet website of such person the information disclosed by such person under subparagraph (A). ${ }^{132}$

In order to comply with the ensuing reporting requirements, relevant multinational corporations would be required to carry out investigations for each fiscal year in order to conclude whether or not persons affected by statelessness are connected to that multinational corporation, whether directly or via a supply chain. The multinational corporations would also need to show how they have conducted the investigations into the problem of statelessness within or connected to their organization. They would also need to take steps to ensure employees have or obtain citizenship and any children the employees may have are registered with the proper authorities. In addition, such multinational corporations would need to monitor the success of their policies, and they also would need to engage with local communities, governments, and agencies to reduce the number of stateless children.

Finally, by way of incentive, multinational corporations may declare that they are "Supporting Stateless Children" if they comply with the disclosure requirements of the provisions. By enabling this declaration and by requiring public disclosure, multinational corporations are raising awareness of the plight of stateless persons and children and have the potential to encourage conscientious investment and consumer choices, while also benefiting from their status as socially conscious employers and organizations.

In the case of statelessness, where the human rights abuse is diverse and widespread, this has the potential to be a particularly effective solution. If part of the responsibility for resolving statelessness is transferred into the hands of multinational corporations, these corporations could help supplement weaknesses in the protection offered by public international law by carrying out the necessary due diligence and audits to determine the scale and causes of the problem persisting

\footnotetext{
Adapted from 15 U.S.C. Section $78 \mathrm{~m}(\mathrm{p})(1)(\mathrm{A})(\mathrm{i})$.

Adapted from 15 U.S.C. Section $78 \mathrm{~m}(\mathrm{p})(1)(\mathrm{A})(\mathrm{ii})$.

Adapted from 15 U.S.C. Section $78 \mathrm{~m}(\mathrm{p})(1)(\mathrm{D})$.

32 Adapted from 15 U.S.C. Section 78m(p)(1)(E).
} 
in their areas of influence. Given their close connection with the host communities, these companies are in the best position to identify, influence, and drive solutions, which cannot be formulated effectively at an international level because of the practical need for diverse local responses.

For example, where the cause of a child's or other person's statelessness is legal or administrative deficiency, ${ }^{133}$ perhaps as the result of the loss of documentation, ${ }^{134}$ a multinational corporation may provide support for proving identity or applying for replacement documents. Where the cause is a lack of understanding or education of migrant workers, or weaknesses in national registration and documentation systems ${ }^{135}$ multinational corporations could be expected to provide guidance, explanations, and systems to ensure the registration of workers and their children. If there is a barrier in the form of a local law or discriminatory practice, ${ }^{136}$ the multinational corporation could be expected to exert pressure on lawmakers to improve policies and to raise awareness among the local population and others to achieve change. While influence may be focused on the employees of multinational corporations and their children, actions taken and policies implemented by such multinational corporations may have the potential to achieve a positive effect beyond their direct sphere of influence.

\section{Legal Precedent for Private Law Solutions for Public Law Challenges}

Although the proposed provision set out in this part is based on conflict minerals legislation, ${ }^{137}$ the existence of legislation designed to engage multinational corporations in combatting human rights abuses is not without precedent outside of the sphere of conflict minerals legislation. The California Transparency in Supply Chains Act of 2010 (the "California Act"), ${ }^{138}$ with effect since January 2012, ${ }^{139}$ seeks to ensure that certain large retailers and manufacturers ${ }^{140}$ provide consumers with information relating to their efforts to eradicate slavery and human trafficking from their supply chains and educate consumers with the aim of improving the lives of victims of slavery and human trafficking. ${ }^{141}$ This is achieved by requiring

133 David Weissbrodt \& Clay Collins, The Human Rights of Stateless Persons, 28 Hum. RTs. Q. 245,253 (2006).

134 Cf. Jerrold W. Huguet \& Sureeporn Punpuing, Child Migrants and Children of Migrants in Thailand, 20 Asia-Pacific Population J. 123, 136 (2005) (discussing the particular problems associated with a lack of documentation).

135 See generally Catherine A. Tobin, No Child Is an Island: The Predicament of Statelessness for Children in the Caribbean, 1 DePaul InT'L Hum. RTs. L.J. 1, 5-6 (2015) (focusing on "[t]he failure of national civil registration and documentation systems, most notably in Haiti).

136 Stacie Kosinski, State of Uncertainty: Citizenship, Statelessness and Discrimination in the Dominican Republic 32 B.C. INT'L \& Comp. L. Rev. 377, 384-395 (2009) (discussing discriminatory practices in the Dominican Republic).

137 Section 1502 of the Dodd-Frank Wall Street Reform and Consumer Protection Act, H.R. 4173.

138 Senate Bill No. 657, Chapter 556.

139 Section 3(c) California Transparency in Supply Chains Act 2010.

140 Those doing business in California with annual worldwide gross receipts in excess of $\$ 100,000,000$, Section 3(a) California Transparency in Supply Chains Act 2010.

${ }_{141} I d$. at Section 2(j). 
disclosure via a "conspicuous and easily understood link"142 on the homepage of the business website ${ }^{143}$ of information relating to such business's supply chains, including verification and audits as well as internal policies and procedures relating to training and internal accountability. ${ }^{144}$ The Modern Slavery Act 2015 (the "U.K. Act") ${ }^{145}$ in the United Kingdom also contains a provision relating to transparency in supply chains. ${ }^{146}$ Like the California Act, the U.K. Act requires certain commercial organizations ${ }^{147}$ to publish a statement ${ }^{148}$ relating to slavery and human trafficking for each financial year ${ }^{149}$ which should include details of the steps taken by the organization to ensure slavery and human trafficking are not taking place in any of its supply chains and in any part of its own business or a statement that the organization has taken no such steps. ${ }^{150}$ The statement, which must be approved and signed by a director, member, or partner of the organization, ${ }^{151}$ may also include information relating to the structure, business, and supply chains of the organization, its policies and due diligence process in relation to slavery and human trafficking, risk areas, the effectiveness of measures taken, and training. ${ }^{152}$

\section{Reporting under Section 1502 of the Dodd-Frank Act}

Notwithstanding various criticisms, ${ }^{153}$ mandatory disclosure remains the hallmark of financial regulation. ${ }^{154}$ Compliance with the disclosure requirements set forth in the Dodd-Frank Act is enforced by the SEC under the Securities and Exchange Act 1934 (the "Exchange Act"). ${ }^{155}$ There are undoubtedly challenges associated with preparing and producing the reports required to comply with the Dodd-Frank Act. ${ }^{156}$ In accordance with Section 1502(d)(3)(C) of the Dodd-Frank Act, the United States Department of Commerce has produced a report listing all known worldwide processing facilities for tin, tungsten, tantalum, and gold, but states that

\footnotetext{
Id. at Section 3(b).

$I d$.

$I d$. at Section 3(c).

Modern Slavery Act 2015.

Id. at Section 54.

147 Commercial organizations carried on in the United Kingdom with a turnover of above $£ 36$ million as set out at Section 2 Modern Slavery Act (Transparency in Supply Chains) Regulations 2015.

148 The organization must make the statement available on its a website if there is one or, if there is not one, the statement must be made available on request. See Section 54(7) Modern Slavery Act 2015.

149 Id. at Section 54(1).

$150 I d$. at Section 54(4).

151 Id. at Section 54(6).

152 Id. at Section 54(5).

153 See generally Omri Ben-Shahar, The Failure of Mandated Discourse, 159 U. PA. L. REv. 647, (2010-2011).

154 Iris H-Y Chiu, Delegated Regulatory Administration in Mandatory Disclosure-Some Observations from EU Securities Regulations, 40 INT'L LAW. 737, 739 (2006).

155 Woody, supra note 7, at 1327-32.

156 See, for example, the limitations and challenges set out in The Department of Commerce Reporting Requirements under Section 1502(d(3)(c) of the Dodd-Frank Act: World-wide Conflict Mineral Processing, available at http://www.trade.gov/industry/materials/Conflict_ Mineral_Executive_Summary_2015.pdf(last visited Aug. 28, 2018).
} 
it is unable to distinguish whether or not a particular facility processes conflict minerals. ${ }^{157}$ The report states that "to ... [ [the authors'] knowledge, the attached list is the most comprehensive list to date of all known processing facilities in the world" 158 but goes on to acknowledge the difficulties faced in compiling the list, noting among other challenges that "[the authors] observed that there is a considerable lack of publicly available information on processing facilities and that there are only a handful of smelter lists created by industry associations and private sector organizations, and publicly available in directories, publications and related resources." 159 The 2015 report is based on the previous year's report ${ }^{160}$ and is subject to the same limitations. ${ }^{161}$

The difficulties faced by the Department of Commerce ${ }^{162}$ are likely to be indicative of the challenges faced by multinational companies in identifying the source of minerals in order to comply with the disclosure requirements of the Securities Exchange Act. ${ }^{163}$ Global Witness and Amnesty International have analyzed 100 conflict minerals reports ${ }^{164}$ made in accordance with Rule $13 p-1$ under the Exchange Act and have found that $79 \%$ of those reports "do not meet the minimum reporting requirements." 165 Despite this, the analysis reveals that over $80 \%$ of companies acknowledged that reporting needed to be improved, and in many cases companies already have plans for making improvements, ${ }^{166}$ suggesting a high level of engagement at a corporate level. Significantly, the report also acknowledges that the Dodd-Frank Act is having an impact in the DRC, where "the government, non-governmental organizations and private businesses have also ramped up efforts to clean up the mining sector, in part to meet the emerging international market demand for clean, 'conflict-free' minerals that has followed the passage of Section 1502." 167

The OECD Due Diligence Guidance provides an agreed method for conducting due diligence into the source of minerals, ${ }^{168}$ which is relied upon by reporting companies in accordance with the SEC Final Rule. ${ }^{169}$ The Chinese Guidelines ${ }^{170}$

168 The OECD Due Diligence Guidance explains it is " $a$ collaborative government-backed multi-stakeholder initiative on responsible supply chain management of minerals from conflict-affected areas." See OECD supra note 95, at 99.

169 See Securities and Exchange Commission, supra note 81, which sets out that the OECD Due Diligence Guidance and is the only nationally or internationally due diligence framework available.

170 See China Chamber of Commerce of Metals, Minerals \& Chemicals Importers \& Exporters, supra note 90.
} 
and the proposed E.U. legislation ${ }^{171}$ also rely on the framework provided by the OECD. The SEC declares in the final rule that it was "persuaded by commentators" that use of the OECD Due Diligence Guidance is helpful to "enhance the quality of an issuer's due diligence, promote comparability of the Conflict Minerals Reports of different issuers, and provide a framework by which auditors can assess an issuer's due diligence." 172 While there is no such guidance in relation to statelessness for companies to base their due diligence investigations, measures, or reports upon, there may be potential to link statutory requirement to address statelessness to the four categories of activities of the UNHCR ${ }^{173}$ relating to identification, prevention, reduction, and protection ${ }^{174}$ in order to provide a framework for the corporateresponse. Furthermore, the UNHCR and Open Society Justice Initiative have produced a report which proposes solutions for reducing statelessness in the United States, ${ }^{175}$ which makes of a number of recommendations ${ }^{176}$ concerning stateless individuals in the United States which, while framed in the context of the United States, may prove useful as a basis for a more broadly applicable framework.

\section{Declaration under Section 1502 of the Dodd-Frank Act}

Section 1502 of the Dodd-Frank Act allows companies the use of the label "DRC conflict free" if its products do not contain conflict minerals that "directly or indirectly finance or benefit armed groups in the [DRC] or an adjoining country." 177 The attempt to use the SEC to require reporting of this nature is controversial. ${ }^{178}$ In addition to fundamental concerns about the purpose of SEC disclosures or disclosure as a method of addressing human rights concerns, ${ }^{179}$ the conflict minerals provisions of the Dodd-Frank Act have been challenged in the U.S. courts. ${ }^{180}$ The National Association of Manufacturers and others challenged the SEC and Amnesty International in the D.C. Circuit. As a result of such litigation, the D.C. Court of Appeals ruled in favor of reporting companies challenging the SEC requirement for indicating that their products have "not been found to be DRC conflict free"

171 See European Parliament, supra note 86.

172 See Securities and Exchange Commission, supra note 81.

173 See generally United Nations High Commissioner for Refugees, http://www.unhcr.org (last visited Aug. 28, 2018).

174 See UNHCR, How UNHCR Helps Stateless People, http://www.unhcr.org/uk/how-unhcrhelps-stateless-people.html (last visited Aug. 28, 2018).

175 Citizens of Nowhere, Solutions for the Stateless in the US, A Report from the United Nations High Commissioner For Refugees and Open Society Justice Initiative (December 2012), available at https://www.opensocietyfoundations.org/sites/default/files/citizens-ofnowhere-solutions-for-the-stateless-in-the-us-20121213.pdf (last visited Aug. 28, 2018).

176 Id. at 30-32.

17715 U.S.C. Section $78 \mathrm{~m}(\mathrm{p})(1)(\mathrm{D})$.

178 See 156 Cong. Rec. S3976, Part C, for a Summary of the Comments on the Proposed Rules.

179 Marcia Narine argues in Disclosing Disclosure's Defects: Addressing Corporate Irresponsibility for Human Rights Impacts, 47 Colum. Hum. RTs. L. Rev. 84 (2015) that disclosure is not an effective method to compel companies to act in respect of human rights violations, arguing that disclosures do not change behavior.

180 National Association of Manufacturers v. Securities and Exchange Commission, No. 135252, (D.C. Cir. 2014). 
in 2014, ${ }^{181}$ recognizing that such a requirement amounts to compelled commercial speech and hence breaches the First Amendment to the U.S. Constitution. ${ }^{182}$ The 2014 ruling was the subject of a statement of the SEC, ${ }^{183}$ confirming that reports required to be filed should "comply with and address those portions of Rule 13p-1 and Form SD that the Court upheld." 184 Notwithstanding the ruling in National Association of Manufacturers v. SEC, ${ }^{185}$ the legislative proposal in respect of the "Supporting Stateless Children" declaration set out in this article should not amount to compelled commercial speech and thus would not be precluded by the decision given that the proposed declaration would be made on a voluntary basis only.

Disclosure under the Dodd-Frank Act enables investors and consumers to make informed choices about their investments and purchases if they choose to have regard to the reports issued with the SEC in accordance with the final rule. ${ }^{186}$ Such disclosure can be used by companies complying with the requisite standards with the aim of having a positive impact on a particular abuse or injustice by raising awareness and guiding consumer and possibly investor behavior. ${ }^{187}$

\section{Transparency}

Like conflict minerals legislation and slavery and human trafficking provisions, the proposed provisions rely on public transparency: disclosure by multinational corporations of actions, policies, and procedures. The provisions do not seek to prescribe how multinational corporations should combat human rights abuses; their effectiveness in alleviating the abuse depends on the engagement and conscience of the investor, the reporting organization, and their consumers.

The incentive to comply on a meaningful level by multinational corporations is provided by investors and consumers who have the power to choose whether or not to support an organization according to their satisfaction with the level of compliance. ${ }^{188}$ A 2015 Resource Guide relating to the California Act claims that "[a] recent law in California is poised to help California consumers make better and more informed purchasing choices." 189 Likewise, the guidance issued under

181 This decision was re-affirmed on petition for panel rehearing by the U.S. Court of Appeals for the District of Columbia Circuit, decided Aug. 18, 2015.

182 See National Association of Manufacturers v. Securities and Exchange Commission, supra note 182 at $18-19$ and 22 ; and $i d$. at 18 and 25 .

183 Statement on the Effect of the Recent Court of Appeals Decision on the Conflict Minerals Rule by Keith F. Higgins, Director, SEC Division of Corporation Finance, April 29, 2014.

184 Id.

185 National Association of Manufacturers v. Securities and Exchange Commission, supra note 182.

186 Securities and Exchange Commission, supra note 81.

187 For discussion of the role of disclosure and market forces in relation to conflict minerals sourcing, see Margaret Ryznar \& Karen E. Woody, A Framework on Mandating versus Incentivizing Corporate Social Responsibility, 98 MARQ. L. REv. 1667 2014-2015 and 156 Cong. Rec. S3976 (May 19, 2010) (statement of Senator Feingold), quoted in the SEC Final Rule, see Securities and Exchange Commission, supra note 83.

188 Id.

189 The California Transparency in Supply Chains Act, A Resource Guide, 2015, Kamala D. Harris, Attorney General of the California Department of Justice, i, available at https://oag. ca.gov/sites/all/files/agweb/pdfs/sb657/resource-guide.pdf (last visited Aug. 28, 2018). 
Section 54(9) of the Modern Slavery Act 2015 notes that the legislation "increase[s] transparency by ensuring the public, consumers, employees and investors know what steps an organisation is taking to tackle modern slavery," 190 which further "allows investors to move capital towards more sustainable, responsible organisations and strengthen the long-term ethical sustainability of the financial system."'191

Although not perfect, empirical data indicate that Dodd-Frank's conflict mineral disclosure provisions have "been partially effective in ensuring increased levels of social disclosure." 192 Whether the "name and shame" approach of DoddFrank ${ }^{193}$ or simple corporate altruism, the impact of the policies, reports, and actions are having on the ground in the DRC is crucial. Further, they may offer an effective template to address child statelessness in global supply chains in a manner in which public law alone cannot eradicate the problem. Indeed, if raising investor awareness and engaging multinational corporations in ethical campaigns can help to drive real change, then ethical codes should be applauded and encouraged. In the present case, raising awareness of the plight of stateless children among these global actors is the first step in this process.

\section{CONCLUSION}

Responding to the complex global challenge of child statelessness requires awareness, engagement, and action. To date, given the myriad of causes and consequences of statelessness, an effective global response based on public law initiatives alone has proven elusive. This article has sought to identify and explore ways in which the private law may be harnessed to contribute to a solution to the persistent problem of child statelessness. How far, to what extent, and how successful any of the initiatives suggested in this article may be depend upon many factors, including not only the scope and reach of legislation or the particular barriers faced by stateless individuals in any given jurisdiction, but also the public awareness of the plight of stateless children and the appetite among the public, investors, governments, and multinational corporations for change. Nevertheless, the engagement of the corporate world offers a pragmatic approach, reaching those directly affected by statelessness, by looking to those multinational corporations active across the globe with the tools and incentives to engage in identifying and pursuing solutions. By emulating the global impact and influence of conflict minerals legislation, the combination of private law initiatives with the public law represents an ambitious and positive step towards the alleviation of child statelessness.

190 UK Government, Transparency in Supply Chains etc.: A Practical Guide, Guidance issued under section 54(9) of the Modern Slavery Act 2015, available at https:/assets.publishing. service.gov.uk/government/uploads/system/uploads/attachment_data/file/649906/ Transparency_in_Supply_Chains_A_Practical_Guide_2017.pdf guide, 3 .

191 Id. at 4.

192 Dalla Via \& Perego, supra note 8.

193 Id. 